Buletin Keslingmas Vol.40 No.2

\title{
PENGARUH PEMAKAIAN CAMPURAN LILIN PARAFIN DAN SERBUK DAUN PEPAYA TERHADAP KEBERADAAN LALAT DI TPS PASAR MANIS PURWOKERTO BANYUMAS
}

\author{
Anita Kusuma Dewi ${ }^{1}$ ), Djamaluddin Ramlan ${ }^{1}$ ), Arif Widyanto ${ }^{1}$ ) \\ $\left.{ }^{1}\right)$ Poltekkes Kemenkes Semarang
}

\begin{abstract}
Abstrak
Lalat merupakan vektor perantara yang dapat membawa patogen pada tubuhnya.. Pengendalian terhadap lalat dapat dilakukan dengan lilin aroma daun papaya, karena kandungan daun papaya dapat mematikan organisme pengganggu. Jenis penelitian Pre Eksperimen dengan rancangan Pre test and post test control group design. Analisis data yang digunakan yaitu analisis univariat dan data hasil penelitian dianalisis dengan menggunakan uji tabel Hasil penelitian terdapat 7 lalat di zona B pada radius nyala lilin dengan jari - jari $8 \mathrm{~cm}$, faktor lingkungan berpengaruh terhadap keberadaan lalat, jenis lalat yang tertangkap di zona B yaitu Musca Domestica dan Lucilia Sericata, dosis yang paling efektif dalam mengusir keberadaan lalat yaitu dosis 30 gram sehingga daun papaya memiliki pengaruh dalam mengusir keberadaan lalat Kesimpulan penelitian adalah serbuk daun papaya 30 gram yang paling efektif dalam mengusir keberadaan lalat. Bagi pihak pengelola pasar manis diharapkan melakukan pengangkutan sampah dari TPS ke TPA 1 kali sehari untuk mengeleminasi tempat perindukan lalat
\end{abstract}

Kata Kunci : Lalat, Lilin parafin, Musca Domestica, Lucilia sericata

\begin{abstract}
Flies are vectors that can carry pathogens at the time . Control of flies can be done with aroma candles of papaya leaves, because the content of papaya leaves can change bullies. Pre-experiment research type with Pre-test and post-test control group design. Analysis of the data used was univariate analysis and the results of research data were analyzed using research tables. Results of the study 7 flies in zone B on the flame radius of Domestica and Lucilia Sericata, the most effective dose in carrying flies ie 30 grams of papaya leaves had an increase in expelling conclusion flies The research is 30 gram papaya leaf powder which is most effective in repelling flies. Market managers are expected to transport waste from TPS to TPA 1 time a day
\end{abstract}

Keywords $\quad$ :Flies, Paraffin Waxs, Musca Domestica, Lucillia Sericata 
I. Pendahuluan

Upaya kesehatan adalah setiap kegiatan dan/atau serangkaian kegiatan yang dilakukan secara terpadu, terintregasi dan berkesinambungan untuk memelihara dan meingkatkan derajat kesehatan masyarakat dalam bentuk pencegahan penyakit, peningkatan kesehatan, pengobatan penyakit, dan pemulihan kesehatan oleh pemerintah dan/atau masyarakat (UU No 36, 2009, h. 4)

Lalat merupakan vektor perantara yang dapat membawa patogen pada tubuhnya. Permukaan tubuhnya yang dipenuhi dengan struktur rambut halus menjadi media pembawa yang baik bagi agen patogen. Perilakunya yang seringkali hinggap pada kotoran, sampah, bangkai dan makanan menjadi faktor penting munculnya penyakit foodborne disease di masyarakat salah satunya yaitu diare (Dicky Andiarsa, dkk. 2015, h.37)

Diare merupakan Penyakit Endemis di Kabupaten Banyumas dan merupakan penyakit potensial KLB yang sering disertai dengan kematian terutama pada daerah yang pengendalian faktor resikonya masih rendah. (Profil Kesehatan Banyumas, 2015, h.19)

Pasar Manis merupakan pasar tradisional yang terletak di Purwokerto bagian barat. Berdasarkan survei awal terdapat banyak lalat dan banyak para pedagang yang mengeluh tentang hal itu. (Agus Subagyo, 2013, h.485)

Pengendalian lalat yang dapat digunakan yaitu penggunaan pestisida nabati yang berasal dari tumbuhan. Berdasarkan penelitian yang dilakukan oleh Konno dalam Julaily et al., (2013), getah pepaya mengandung kelompok enzim sistein protease seperti papain dan kimopapain. Getah pepaya juga menghasilkan senyawa-senyawa golongan alkaloid, terpenoid, flavonoid dan asam amino nonprotein yang sangat beracun bagi serangga pemakan tumbuhan. (Prehatin Trirahayu Ningrum, 2010, h.81)

Berdasarkan latar belakang peneliti ingin melakukan inovasi baru dalam pengendalian lalat melalui judul penelitian "pengaruh pemakaian campuran lilin parafin dan serbuk daun pepaya terhadap keberadaan lalat di TPS Pasar Manis Purwokerto Banyumas" dengan harapan dapat mengusir keberadaan lalat yang dapat menjadi perantara penyakit diare.

II. Bahan dan Metode

Serbuk daun pepaya yang dibuat dengan cara dikeringkan dibawah sinar matahari kemudian ditumbuk dan disaring untuk diambil serbuknya kemudian diolah menjadi satu dengan lilin parafin sehingga menjadi lilin aroma. Penelitian dilakukan selama 3 hari dengan 3 kali pengulangan (pagi, siang, sore). Jenis penelitian yang digunakan yaitu Pre Eksperimen dengan rancangan Pre test and post test control group design. Analisis data yang digunakan yaitu analisis univariat dengan menggambarkan lokasi penelitian dan data disajikan dalam bentuk tabel. Data hasil penelitian dianalisis dengan menggunakan uji tabel.

III. Hasil dan Pembahasan

A. Gambaran Umum Lokasi

Pasar Manis Purwokerto merupakan salah satu pasar tradisional yang terletak di jalan Jend. Gatot Subroto. Pedagang yang berjualan di Pasar Manis Purwokerto berasal dari wilayah Banyumas ataupun luar Banyumas. Secara keseluruhan jumlah pedagang sebanyak 517 pedagang.

Jenis komoditas yang diperjualbelikan meliputi kebutuhan pokok sehari-hari seperti bahan makanan, makanan, buah-buahan, ikan segar dan daging, pakaian, barang kelontong, perhiasan serta masih banyak lainnya.

Konstruksi bangunan di Pasar Manis yaitu atap kuat, tidak bocor, dan tidak menjadi tempat berkembangbiaknya binatang penular penyakit, dinding bersih, berwarna terang, dan tidak lembab, lantai kedap air, permukaan rata dan tidak licin, tidak retak dan mudah dibersihkan. Kondisi tersebut sudah sesuai dengan persyaratan yang di tetapkan dalam PERMENKES No 519 Tahun 2008 tentang persyaratan Kesehatan Lingkungan Pasar.

Air bersih yang digunakan berasal dari air tanah. Kualitas air bersih diperiksa setiap 1 tahun sekali dengan parameter yang diperiksa yaitu fisik, kimia, dan bakteriologis

Toilet yang terdapat di Pasar Manis ada pemisahan antara Toilet pria dan wanita, serta sudah menggunakan leher angsa dan pembuangannya disalurkan ke septic tank.

Aktifitas di Pasar Manis Purwokerto dimulai pukul 06.00 sampai pukul 15.00 WIB. Dalam kurun waktu \pm selama 10 jam terjadi aktifitas jual beli yang dapat menghasilkan sampah dengan klasifikasi sampah plastik, sampah sayuran, sampah buah, sampah hasil dari pembersihan jeroan ayam atau ikan dan lain-lain. Sampah tersebut dikumpulkan di dalam tempat sampah yang sudah disediakan oleh pengelola sampah. 
Setelah sampah terkumpul pengelola sampah yang berjumlah \pm 8 orang mengangkut sampah tersebut ke TPS Pasar Manis.

Sampah pada TPS ini bukan hanya berasal dari aktifitas Pasar namun banyak juga warga Kelurahan Kedungwuluh yang buang sampah ke TPS Pasar Manis.

Volume tumpukan sampah di TPS pasar manis \pm 1 ton/ hari. Dengan volume yang banyak ini seharusnya pengangkutan sampah dari TPS ke TPA dilakukan $1 \times$ sehari namun pada kenyataannya pada saat kami melakukan penelitian ternyata sampah yang berada di TPS itu sudah 3 hari baru dilakukan pengangkutan hal ini menyebabkan volume bak penampungan sampah lebih banyak dan akibatnya dapat menjadi sarang vektor mekanis dan binatang pengganggu.

TPS Pasar Manis Purwokerto ini terbuat dari konstruksi bangunan yang terbuka, dengan spesifikasi sebagai berikut: Ukuran bangunan kurang lebih $24 \mathrm{~m} 2$, Jarak TPS dengan pasar $\leq 10 \mathrm{~m}$. Konstruksi atap kuat, tidak bocor, dan tidak menjadi tempat berkembangbiaknya binatang penular penyakit, dinding bersih, berwarna terang, dan tidak lembab, lantai kedap air, permukaan rata dan tidak licin, tidak retak dan mudah dibersihkan. Terdapat alat penunjang berupa 4 gerobag sampah Jumlah petugas pengelola sampah 8 orang. Kontruksi tersebut sudah sesuai dengan PERMENKES No.519/MENKES/SK/VI/2008 tentang syarat TPS

B. Hasil Riset

1. Menentukan keberadaan lalat di area nyala lilin

Berdasarkan hasil penelitian untuk menentukan keberadaan lalat peneliti melakukan survai secara langsung untuk memastikan adanya lalat, setelah itu peneliti meletakkan sampling frame yang dapat dilihat pada gambar 1 dimana zona A yang berwarna merah merupakan sampling frame yang dibuat dari karton berukuran $90 \times 90 \mathrm{~cm}$ dan dijadikan sebagai alas untuk meletakkan lilin sedangkan zona B yang berwarna kuning dengan jari - jari $8 \mathrm{~cm}$ merupakan sampling frame yang dijadikan sebagai area perhitungan yang menggunakan acuan bayangan lilin

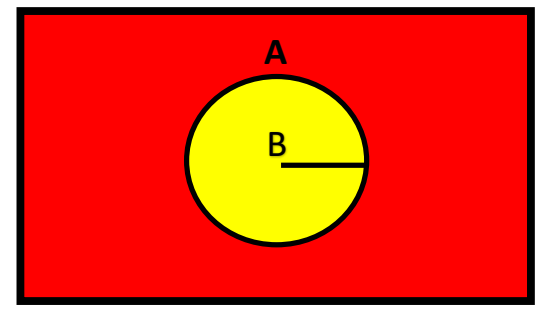

Gambar 1 Sampling frame

TPS pasar Manis merupakan lokasi padat lalat. Sebelum dilakukan penelitian, peneliti meletakkan sampling frame zona A untuk melihat apakah lalat akan hinggap atau tidak dan hasilnya banyak lalat yang hinggap di ujung - ujung kardus, setelah itu peneliti meletakkan lilin di sampling frame zona B di titik tengah dengan jari - jari $8 \mathrm{~cm}$ dari jarak terluar zona B. Berikut hasil perhitungan jumlah lalat di sampling frame zona $\mathrm{B}$

Tabel 1 Hasil Perhitungan Jumlah Lalat dengan Aplikasi Lilin Parafin dan Serbuk Daun Pepaya

\begin{tabular}{|c|c|c|c|c|c|c|}
\hline \multirow{3}{*}{ NO } & \multicolumn{2}{|c|}{$\begin{array}{c}\text { Waktu } \\
\text { Perlakuan }\end{array}$} & \multicolumn{4}{|c|}{ Jumlah Lalat Pada Perlakuan } \\
\hline & \multirow[b]{2}{*}{ Waktu } & \multirow{2}{*}{$\begin{array}{c}\text { Hari } \\
\text { ke }\end{array}$} & \multirow{2}{*}{$\begin{array}{l}\text { Sebelum } \\
\text { (Kontrol) }\end{array}$} & \multicolumn{3}{|c|}{ Sesudah } \\
\hline & & & & $\begin{array}{l}\text { Dosis } \\
10 \mathrm{gr}\end{array}$ & $\begin{array}{l}\text { Dosis } \\
20 \mathrm{gr}\end{array}$ & $\begin{array}{l}\text { Dosis } \\
30 \mathrm{gr}\end{array}$ \\
\hline \multirow[t]{4}{*}{1} & Pagi & 1 & 0 & 0 & 1 & 0 \\
\hline & & 2 & 1 & 1 & 0 & 0 \\
\hline & & 3 & 0 & 0 & 0 & 0 \\
\hline & \multicolumn{2}{|l|}{ Rata-rata } & 0,33 & 0,33 & 0,33 & 0 \\
\hline \multirow[t]{4}{*}{2} & Siang & 1 & 0 & 0 & 0 & 0 \\
\hline & & 2 & 1 & 0 & 0 & 0 \\
\hline & & 3 & 0 & 0 & 1 & 1 \\
\hline & \multicolumn{2}{|l|}{ Rata-rata } & 0,33 & 0 & 0,33 & 0,33 \\
\hline \multirow[t]{3}{*}{3} & Sore & 1 & 0 & 1 & 0 & 0 \\
\hline & & 2 & 0 & 0 & 0 & 0 \\
\hline & & 3 & 0 & 0 & 0 & 0 \\
\hline \multicolumn{3}{|c|}{ Rata-rata } & 0 & 0,33 & 0 & 0 \\
\hline
\end{tabular}

Penelitian ini menggunakan 4 perlakuan berbeda dengan 1 kontrol dan 3 perlakuan variasi dosis. pada perlakuan kontrol terdapat 1 lalat yang hinggap di sampling frame zona B pada pagi di hari ke dua dan siang 
di hari ke dua, pada perlakuan 10 gram terdapat 1 lalat yang hinggap di sampling frame zona B pada pagi di hari ke dua dan sore di hari pertama, pada perlakuan 20 gram terdapat 1 lalat yang hinggap di sampling frame zona B pada pagi di hari pertama dan siang di hari ke tiga, sedangkan pada perlakuan 30 gram terdapat 1 lalat yang hinggap di sampling frame zona $B$ pada siang di hari ke tiga.

Hasil tersebut di dapatkan selama pemaparan 10 menit per perlakuan. Waktu 10 menit di dasarkan pada penelitian Septa Raharja dkk (2006) yang menyatakan bahwa hasil pendeteksian terbaik lilin aromaterapi yaitu antara 0,06 sampai 100,9 detik, dan setiap pergantian perlakuan diberi jeda selama 10 menit untuk menghilangkan aroma yang dikeluarkan dari perlakuan sebelumnya.

$$
\text { Keberadaan lalat juga }
$$

dikarenakan adanya faktor pendukung yaitu sumber makanan bagi lalat, keadaan suhu dan kelembaban. Selain itu keberadaan lalat dapat dijadikan indikator baik buruknya sanitasi di suatu tempat (Agus Subagyo, dkk. 2013. h.484)

Penentuan sampling frame zona A yang terbuat dari karton berukuran $90 \times 90 \mathrm{~cm}$ disesuaikan dengan ukuran fly grill standar. Fungsi sampling frame untuk meletakkan lilin sedangkan penentuan bentuk persegi didasarkan pada sifat lalat yang cenderung hinggap pada tepi atau tempat yang bersudut tajam serta sampling frame zona $\mathrm{B}$ yang berwarna kuning dengan jari - jari 8 $\mathrm{cm}$ merupakan sampling frame yang dijadikan sebagai area perhitungan dengan menggunakan acuan bayangan lilin

2. Menghitung jumlah lalat yang berada di area nyala lilin

Hasil penelitian selama tiga hari untuk menghitung jumlah lalat yang berada diarea nyala lilin dapat dilihat pada. tabel 1 dengan total 7 lalat yang berada di area nyala lilin pada seluruh perlakuan Hasil diatas menunjukan bahwa daun papaya dapat dijadikan sebagai bahan pestisida alami karena diketahui mengandung 35mg/ 100mg tocophenol.

Sementara itu, daun pepaya juga diketahui banyak mengandung zat bernama alkaloid dan enzim papain. Enzim ini identik dengan getah berwarna putih kental.

Menurut Kotaro Konno et al., (2004) melaporkan, bahwa getah pepaya (Carica pepaya L.) mengandung kelompok enzim hydrolase sistein proteolitik seperti papain sebanyak 10\%, Khimoprotein sebanyak $45 \%$ dan juga Lisozim sebanyak $20 \%$.

Daun pepaya juga diketahui banyak mengandung senyawa golongan alkaloid, terpenoid, flavonoid dan asam amino yaitu suatu substansi yang bersifat basa, mengandung satu atau lebih atom nitrogen dan seringkali bersifat toksitas (membunuh) sehingga dapat digunakan untuk mengendalikan hama.

Menurut penelitian Yuli Patmasari dkk menjelaskan bahwa lalat tidak menyukai bau yang dikeluarkan dari bahan aktif yang terkandung di dalam tanaman. Hal itu dapat dilihat pada hasil penelitian yang menunjukan bahwa lilin yang paling efektif menurunkan angka kepadatan lalat adalah lilin yang ditambahkan minyak serai wangi sebesar $12 \%$. Perlakuan menggunakan lilin tersebut dapat menurunkan angka kepadatan lalat sebesar 34,27\%.

Penurunan angka kepadatan lalat juga dipengaruhi oleh konsentrasi minyak serai wangi yang ditambahkan dalam masing - masing lilin padat perbedaan konsentrasi tersebut mempengaruhi banyaknya bahan aktif yang terdapat pada minyak serai wangi. Semakin tinggi konsentrasi minyak serai wangi maka semakin tinggi pula kontak sitronelol dan geraniol terhadap organ tubuh lalat.

3. Mengidentifikasi jenis lalat yang terdapat disekitar nyala lilin

Berdasarkan penelitian yang telah dilaksankan selama tiga hari untuk mengetahui hasil identifikasi jenis lalat yang tertangkap dapat dilihat pada tabel 2 
Tabel 2 Hasil Identifikasi Jenis Lalat

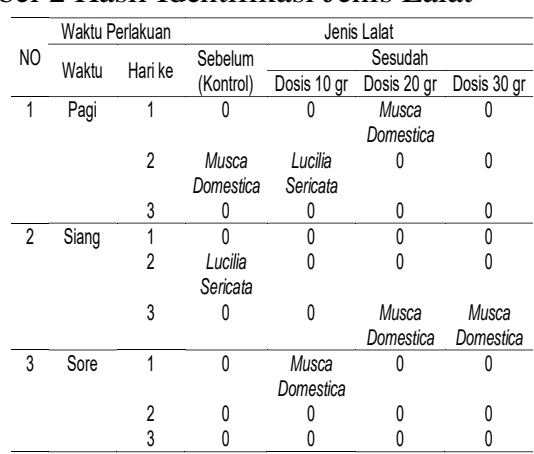

Pada penelitian ini peneliti melakukan mengidentifikasi lalat yang tertangkap disekitar nyala lilin dengan bantuan kunci identifikasi. Sesuai tabel 2 jenis lalat yang tertangkap yaitu jenis lalat Musca Domestica dan jenis lalat Lucilia Sericata. Dari pengamatan yang telah dilakukan tanda-tanda morfologi tubuh lalat Musca Domestica yaitu warna tubuh abu-abu kehitaman, pada bagian abdomen berwarna kuning orange dan ujungnya coklat kehitaman. Pada bagian permukaan atas thorax terdapat 4 garis berwarna hitam. Panjang tubuh $7 \mathrm{~mm}$. Kepalanya besar berwarna coklat gelap, mata besar menonjol dan terpisah. Dan tanda-tanda morfologi tubuh lalat Lucilia Sericata yaitu warna tubuh hijau metalik, panjang tubuh $9 \mathrm{~mm}$, thorax dan abdomen bewarna hijau metalik.

Menurut Nani Kurnia dkk menyatakan bahwa Lucilia Sericata mengalami metamorfosis sempurna yang dimulai dari tahapan telur, larva yang terdiri dari tiga tahapan instar, pupa, dan imago (lalat dewasa). Seluruh siklus hidup dari Lucilia Sericata secara alami berlangsung sekitar 11-14 hari.

Menurut Endang Puji Astuti dan Firda Yanuar Pradani menyatakan bahwa Perkembangan setiap stadium dari Musca domestica sangat dipengaruhi oleh kondisi lingkungan (kelembaban tinggi), ketersediaan makanan dan daya adaptasi dari lalat. Seluruh siklus hidup lalat Musca domestica mulai dari telur sampai dewasa membutuhkan waktu berkisar 11 - 15 hari.

Menurut Puguh Wahyudi dkk dalam Hestiningsih et al (2003) Menyatakan bahwa Infestasi lalat rumah dan lalat hijau berdampak negatif terhadap kesehatan manusia di seluruh dunia. Lalat ini tersebar secara kosmopolit dan bersifat sinantropik yang artinya lalat mempunyai ketergantungan yang tinggi (berasosiasi) dengan kehidupan manusia karena sumber pakan lalat sebagian besar ada pada makanan manusia

4. Mendeskripsikan faktor lingkungan fisik meliputi suhu, kelembaban, kecepatan angin, dan pencahayaan

Berdasarkan hasil perhitungan jumlah lalat yang berada di area nyala lilin yang dilakukan di Pasar Manis Purwokerto dipengaruhi oleh berbagai macam faktor.

Faktor tersebut diantaranya adalah aktifitas masyarakat di sekitar pasar yang berlalu - lalang untuk pergi ke pasar atau sekedar buang sampah di TPS serta dapat dipengaruhi oleh kondisi fisik seperti suhu, kelembaban, kecepatan angin, dan pencahayaan yang ada di TPS. Berikut hasil pengukuran kondisi lingkungan di lokasi penelitian

Tabel 3 Hasil Pengukuran suhu

\begin{tabular}{|c|c|c|c|c|c|c|}
\hline \multirow{3}{*}{ NO } & \multicolumn{2}{|c|}{ Waktu Perlakuan } & \multicolumn{4}{|c|}{ Hasil Pengukuran Suhu } \\
\hline & \multirow{2}{*}{ Waktu } & \multirow{2}{*}{ Harike- } & \multirow{2}{*}{$\begin{array}{l}\text { Sebelum } \\
\text { (Kontrol) }\end{array}$} & \multicolumn{3}{|c|}{ Sesudah } \\
\hline & & & & Dosis $10 \mathrm{gr}$ & Dosis $20 \mathrm{gr}$ & Dosis $30 \mathrm{gr}$ \\
\hline \multirow[t]{4}{*}{1} & Pagi & 1 & $25,6^{\circ} \mathrm{C}$ & $27^{\circ} \mathrm{C}$ & $27,5^{\circ} \mathrm{C}$ & $27,8^{\circ} \mathrm{C}$ \\
\hline & & 2 & $29,4^{\circ} \mathrm{C}$ & $30,7^{\circ} \mathrm{C}$ & $29,9^{\circ} \mathrm{C}$ & $30^{\circ} \mathrm{C}$ \\
\hline & & 3 & $30^{\circ} \mathrm{C}$ & $31,9^{\circ} \mathrm{C}$ & $30,1^{\circ} \mathrm{C}$ & $29,9^{\circ} \mathrm{C}$ \\
\hline & \multicolumn{2}{|c|}{ Rata - rata } & $28,3^{\circ} \mathrm{C}$ & $29,9^{\circ} \mathrm{C}$ & $29,1^{\circ} \mathrm{C}$ & $29,2^{\circ} \mathrm{C}$ \\
\hline \multirow[t]{4}{*}{2} & Siang & 1 & $27,6^{\circ} \mathrm{C}$ & $27,5^{\circ} \mathrm{C}$ & $29,2^{0} \mathrm{C}$ & $29,3^{\circ} \mathrm{C}$ \\
\hline & & 2 & $29,4^{\circ} \mathrm{C}$ & $29,7^{\circ} \mathrm{C}$ & $30,9^{\circ} \mathrm{C}$ & $31,5^{\circ} \mathrm{C}$ \\
\hline & & 3 & $30,1^{\circ} \mathrm{C}$ & $30,3^{\circ} \mathrm{C}$ & $29,4^{\circ} \mathrm{C}$ & $28,9^{\circ} \mathrm{C}$ \\
\hline & \multicolumn{2}{|c|}{ Rata - rata } & $29^{\circ} \mathrm{C}$ & $29,1^{\circ} \mathrm{C}$ & $29,8^{\circ} \mathrm{C}$ & $29,9^{\circ} \mathrm{C}$ \\
\hline \multirow[t]{4}{*}{3} & Sore & 1 & $29,3^{\circ} \mathrm{C}$ & $30,3^{\circ} \mathrm{C}$ & $30,2^{\circ} \mathrm{C}$ & $30,2^{\circ} \mathrm{C}$ \\
\hline & & 2 & $30^{\circ} \mathrm{C}$ & $30,6^{\circ} \mathrm{C}$ & $30,8^{\circ} \mathrm{C}$ & $30,4^{\circ} \mathrm{C}$ \\
\hline & & 3 & $28,7^{\circ} \mathrm{C}$ & $30^{\circ} \mathrm{C}$ & $30,5^{\circ} \mathrm{C}$ & $30,1^{\circ} \mathrm{C}$ \\
\hline & \multicolumn{2}{|c|}{ Rata - rata } & $29,3^{\circ} \mathrm{C}$ & $30,3^{0} \mathrm{C}$ & $30,5^{0} \mathrm{C}$ & $30,2^{\circ} \mathrm{C}$ \\
\hline
\end{tabular}

Tabel 4 Hasil Pengukuran Kelembaban

\begin{tabular}{|c|c|c|c|c|c|c|}
\hline \multirow{3}{*}{ NO } & \multicolumn{2}{|c|}{ Waktu Perlakuan } & \multicolumn{4}{|c|}{ Hasil Pengukuran Kelembaban } \\
\hline & \multirow{2}{*}{ Waktu } & \multirow{2}{*}{ Hari ke } & \multirow{2}{*}{$\begin{array}{l}\text { Sebelum } \\
\text { (Kontrol) }\end{array}$} & \multicolumn{3}{|c|}{ Sesudah } \\
\hline & & & & Dosis $10 \mathrm{gl}$ & Dosis $20 \mathrm{~g}$ & Dosis $30 \mathrm{~g}$ \\
\hline \multirow[t]{4}{*}{1} & Pagi & 1 & $89 \%$ & $86 \%$ & $83 \%$ & $81 \%$ \\
\hline & & 2 & $82 \%$ & $81 \%$ & $72 \%$ & $81 \%$ \\
\hline & & 3 & $79 \%$ & $73 \%$ & $75 \%$ & $73 \%$ \\
\hline & \multicolumn{2}{|c|}{ Rata - rata } & $83 \%$ & $80 \%$ & $77 \%$ & $78 \%$ \\
\hline \multirow[t]{4}{*}{2} & Siang & 1 & $86 \%$ & $88 \%$ & $84 \%$ & $82 \%$ \\
\hline & & 2 & $80 \%$ & $78 \%$ & $67 \%$ & $68 \%$ \\
\hline & & 3 & $75 \%$ & $68 \%$ & $74 \%$ & $80 \%$ \\
\hline & \multicolumn{2}{|c|}{ Rata - rata } & $80 \%$ & $78 \%$ & $75 \%$ & $77 \%$ \\
\hline \multirow[t]{4}{*}{3} & Sore & 1 & $72 \%$ & $70 \%$ & $71 \%$ & $72 \%$ \\
\hline & & 2 & $80 \%$ & $69 \%$ & $69 \%$ & $70 \%$ \\
\hline & & 3 & $81 \%$ & $68 \%$ & $67 \%$ & $70 \%$ \\
\hline & \multicolumn{2}{|c|}{ Rata - rata } & $78 \%$ & $69 \%$ & $69 \%$ & $71 \%$ \\
\hline
\end{tabular}

Tabel 5 Hasil Pengukuran Kecepata Angin 
Tabel 6 Hasil

PengukuranPencahayaan

Berdasarkan pengukuran suhu selama tiga hari pada waktu pagi, siang, sore didapatkan rata - rata hasil

\begin{tabular}{|c|c|c|c|c|c|c|}
\hline \multirow{3}{*}{ NO } & \multicolumn{2}{|c|}{ Waktu Perlakuan } & \multicolumn{4}{|c|}{ Hasil Pengukuran Kecepatan Angin } \\
\hline & \multirow{2}{*}{ Waktu } & \multirow{2}{*}{ Hari ke } & \multirow{2}{*}{$\begin{array}{l}\text { Sebelum } \\
\text { (Kontrol) }\end{array}$} & \multicolumn{3}{|c|}{ Sesudah } \\
\hline & & & & Dosis $10 \mathrm{gr}$ & Dosis $20 \mathrm{gr}$ & Dosis $30 \mathrm{gr}$ \\
\hline \multirow[t]{3}{*}{1} & \multirow[t]{3}{*}{ Pagi } & 1 & $0,0 \mathrm{~m} / \mathrm{s}$ & $0,0 \mathrm{~m} / \mathrm{s}$ & $0,0 \mathrm{~m} / \mathrm{s}$ & $0,0 \mathrm{~m} / \mathrm{s}$ \\
\hline & & 2 & $0,0 \mathrm{~m} / \mathrm{s}$ & $0,0 \mathrm{~m} / \mathrm{s}$ & $0,0 \mathrm{~m} / \mathrm{s}$ & $0,0 \mathrm{~m} / \mathrm{s}$ \\
\hline & & 3 & $0,0 \mathrm{~m} / \mathrm{s}$ & $0,0 \mathrm{~m} / \mathrm{s}$ & $0,0 \mathrm{~m} / \mathrm{s}$ & $0,0 \mathrm{~m} / \mathrm{s}$ \\
\hline & \multicolumn{2}{|c|}{ Rata - rata } & $0,0 \mathrm{~m} / \mathrm{s}$ & $0,0 \mathrm{~m} / \mathrm{s}$ & $0,0 \mathrm{~m} / \mathrm{s}$ & $0,0 \mathrm{~m} / \mathrm{s}$ \\
\hline \multirow[t]{4}{*}{2} & \multirow[t]{3}{*}{ Siang } & 1 & $0,0 \mathrm{~m} / \mathrm{s}$ & $0,0 \mathrm{~m} / \mathrm{s}$ & $0,0 \mathrm{~m} / \mathrm{s}$ & $0,0 \mathrm{~m} / \mathrm{s}$ \\
\hline & & 2 & $0,0 \mathrm{~m} / \mathrm{s}$ & $0,0 \mathrm{~m} / \mathrm{s}$ & $0,0 \mathrm{~m} / \mathrm{s}$ & $0,0 \mathrm{~m} / \mathrm{s}$ \\
\hline & & 3 & $0,0 \mathrm{~m} / \mathrm{s}$ & $0,0 \mathrm{~m} / \mathrm{s}$ & $0,0 \mathrm{~m} / \mathrm{s}$ & $0,0 \mathrm{~m} / \mathrm{s}$ \\
\hline & \multicolumn{2}{|c|}{ Rata - rata } & $0,0 \mathrm{~m} / \mathrm{s}$ & $0,0 \mathrm{~m} / \mathrm{s}$ & $0,0 \mathrm{~m} / \mathrm{s}$ & $0,0 \mathrm{~m} / \mathrm{s}$ \\
\hline \multirow[t]{4}{*}{3} & \multirow[t]{3}{*}{ Sore } & 1 & $0,0 \mathrm{~m} / \mathrm{s}$ & $0,0 \mathrm{~m} / \mathrm{s}$ & $0,0 \mathrm{~m} / \mathrm{s}$ & $0,0 \mathrm{~m} / \mathrm{s}$ \\
\hline & & 2 & $0,0 \mathrm{~m} / \mathrm{s}$ & $0,0 \mathrm{~m} / \mathrm{s}$ & $0,0 \mathrm{~m} / \mathrm{s}$ & $0,0 \mathrm{~m} / \mathrm{s}$ \\
\hline & & 3 & $0,0 \mathrm{~m} / \mathrm{s}$ & $0,0 \mathrm{~m} / \mathrm{s}$ & $0,0 \mathrm{~m} / \mathrm{s}$ & $0,0 \mathrm{~m} / \mathrm{s}$ \\
\hline & Rata- - & & $0,0 \mathrm{~m} / \mathrm{s}$ & $0,0 \mathrm{~m} / \mathrm{s}$ & $0,0 \mathrm{~m} / \mathrm{s}$ & $0,0 \mathrm{~m} / \mathrm{s}$ \\
\hline
\end{tabular}

untuk perlakuan kontrol pada waktu pagi $28,30 \mathrm{C}$ pada waktu siang $290 \mathrm{C}$ pada waktu sore 29,30C, untuk perlakuan 10 gram pada waktu pagi 29,90C pada waktu siang 29,10C pada waktu sore $30,30 \mathrm{C}$, untuk perlakuan 20 gram pada waktu pagi 29,10C pada waktu siang 29,80C pada waktu sore $30,50 \mathrm{C}$ dan untuk perlakuan 30 gram pada waktu pagi 29,20C pada waktu siang 29,90C pada waktu sore 30,20C. Untuk pengukuran kelembaban kontrol pada waktu pagi $83 \%$ pada waktu siang $80 \%$ pada waktu sore $81 \%$, untuk perlakuan 10 gram pada waktu pagi $80 \%$ pada waktu siang $78 \%$ pada waktu sore $69 \%$, untuk perlakuan 20 gram pada waktu pagi $77 \%$ pada waktu siang $75 \%$ pada waktu sore $69 \%$ dan untuk perlakuan 30 gram pada waktu pagi $78 \%$ pada waktu siang $77 \%$ pada waktu sore $71 \%$.

Depkes RI (1991) menjelaskan bahwa lalat mulai terbang pada temperatur $150 \mathrm{C}$ dan aktifitas optimumnya pada temperatur 210C. Pada temperatur di bawah 7,50C tidak aktif dan di atas 450C terjadi kematian pada lalat. Menurut Ditjen PPM dan PL (2001, h.6) lalat akan berkembangbiak secara optimum pada kelembaban $90 \%$.

Berdasarkan hasil pengukuran suhu dan kelembaban yang dilakukan dapat dikatakan bahwa kelembaban udara sangat berpengaruh bagi kepadatan lalat, hal ini dijelaskan bahwa jika suhu udara dibawah atau dingin maka kelembaban udara tinggi yang juga diikuti oleh perubahan tingkat kepadatan lalat yang menunjukkan tingkat kepadatan lalat meningkat. Dengan bertambahnya kelembaban suatu lokasi maka kepadatan lalat meningkat (Desta Puji Rusiana. 2018. h.32)

Hasil pengukuran kecepatan angin selama tiga hari pada waktu pagi, siang, sore didapatkan rata - rata $0,0 \mathrm{~m} / \mathrm{s}$ untuk setiap perlakuan. Pengukuran ini menggunakan alat Anemometer milik Laboratorium kampus 7 yang kemungkinan terdapat kendala pada alat tersebut sehingga pengukuran tidak dapat terdeteksi. Padahal kecepatan angin berpengaruh bagi kepadatan lalat, hal ini dijelaskan bahwa jika kecepatan angin rendah maka lalat akan meningkat dan apabila kecepatan angin kencang (tinggi) maka lalat yang hinggap sedikit atau menurun (Desta Puji Rusiana, 2018, h.32)

Pencahayaan di Pasar manis pada saat pengukuran memanfaatkan sinar matahari (alami). Berdasarkan pengukuran pencahayaan selama tiga hari pada waktu pagi, siang, sore didapatkan rata - rata hasil untuk perlakuan kontrol pada waktu pagi 332 Lux pada waktu siang 271,9 Lux pada waktu sore 833,8 Lux, untuk perlakuan 10 gram pada waktu pagi 400,1 Lux pada waktu siang 469,2 Lux pada waktu sore 819,4 Lux, untuk perlakuan 20 gram pada waktu pagi 351,8 Lux pada waktu siang 430 Lux pada waktu sore 582,4 Lux dan untuk perlakuan 30 gram pada waktu pagi 446,6 Lux pada waktu siang 465,4 Lux pada waktu sore 503,4 Lux. Menurut Ditjen PPM dan PL (2001, h. 6) lalat merupakan serangga yang bersifat fototropik yaitu menyukai cahaya. Pada malam hari tidak efektif, namun dapat aktif dengan adanya sinar buatan.

Menurut Fitriana Puspitasari dkk (2017) dalam Diclaro (2012) menyatakan bahwa lalat mengandalkan refleksi sinar matahari untuk mendeteksi objek di lingkungannya ketika terbang, mencari makanan, dan mencari tempat istirahat. Refleksi cahaya masuk ke dalam komponen mata atau ocelli dan menstimulus sel fotosensitif yang memicu 
phototransduction, yaitu konversi cahaya foton menjadi sinyal elektik untuk dideteksi oleh sistem syaraf, dan mengirim sinyal ke lobus optik serangga untuk diinterpretasi.

Efek sinar pada lalat tergantung sepenuhnya pada temperatur dan kelembaban karena dapat menjadikan lalat berkembangbiak secara optimum, pencahayaannya pun dapat dijadikan kondisi yang mempengaruhi adanya suatu kepadatan lalat di tempat tersebut

5. Menentukan efektifitas variasi dosis perlakuan serbuk daun pepaya (10gr, 20gr, 30gr) dalam mengusir keberadaan lalat di Tps Pasar Manis Purwokerto Banyumas

Hasil penelitian menunjukan bahwa variasi dosis 30 gram mampu mengusir keberadaan lalat walaupun ada 1 lalat yang hinggap di sampling frame zona B pada gambar 1 yaitu pada waktu siang di hari ke tiga. Dengan rincian yaitu pada perlakuan kontrol terdapat 1 lalat yang hinggap di sampling frame zona B pada pagi di hari ke dua dan siang di hari ke dua, pada perlakuan 10 gram terdapat 1 lalat yang hinggap di sampling frame zona B pada pagi di hari ke dua dan sore di hari pertama, pada perlakuan 20 gram terdapat 1 lalat yang hinggap di sampling frame zona $\mathrm{B}$ pada pagi di hari pertama dan siang di hari ke tiga, sedangkan pada perlakuan 30 gram terdapat 1 lalat yang hinggap di sampling frame zona $B$ pada siang di hari ke tiga.

Hasil tersebut tidak lepas dari kondisi lingkungan dan faktor pengganggu yang tidak bisa dikendalikan oleh peneliti. Menurut Handi Setiawan dan Anak Agung Oka (2015, h.55) Daun pepaya (Carica papaya L.) mengandung senyawa toksik seperti saponin, alkaloid karpain, papain, flavonoid (Intan, 2012) Senyawa papain merupakan racun kontak yang masuk ke dalam tubuh serangga melalui lubanglubang alami dari tubuh serangga.

Menurut Triana Wulandari (2017) menyatakan bahwa Pestisida organik ekstrak daun pepaya pada semua perlakuan yaitu fase daun muda, dewasa, tua konsentrasi 150 $\mathrm{g} / \mathrm{l}, 200 \mathrm{~g} / \mathrm{l}$ dan $250 \mathrm{~g} / \mathrm{l}$ memberikan tingkat kematian yang sama dengan pestisida Profenofos 100 g/l, yaitu sebesar 100\%. Hal ini disebabkan daun pepaya mempunyai senyawa yang bersifat toksik merusak jaringan saraf. Enzim papain juga dapat bekerja sebagai enzim protase yang dapat menyerang dan melarutkan komponen penyusun kutikula serangga (Trizelia, 2001).

Wiratno (2010) mengemukakan bahwa penggunaan ekstrak daun pepaya dapat memutuskan atau menggagalkan metamorfosis sempurna. Saponin jika dikonsumsi oleh serangga dapat menurunkan aktivitas enzim pencernaan dan penyerapan makanan (Applebaum et al., 1969). Saponin juga dapat menurunkan tegangan permukaan selaput kulit larva serta mampu mengikat sterol bebas dalam pencernaan makanan (Gershezon dan Croteau, 1991). Sterol merupakan prekusor dari hormon ekdison sehingga dengan menurunnya persediaan sterol akan menganggu proses ganti kulit pada serangga.

Daun pepaya kering dapat memudahkan kandungan senyawa organik keluar dari dalam lapisan daun. Pada permukaan daun yang kering, akan memudahkan bahan aktif yang terkandung dalam daun pepaya keluar sehingga bahan aktif racun dapat bekerja secara efektif dalam membunuh hama Aphis sp. Seperti yang dikatakan (Lakitan, 1999) bahan kering memiliki kandungan kimia organik yang lebih tinggi jika dibandingkan dengan bahan segar.

Lalat merupakan salah satu serangga yang mempunyai penciuman yang tajam. Indera penciuman yang dimiliki lalat sangat peka. Bahkan mereka dapat mencium makanannya hingga 2 kilometer jauhnya.

6. Menganalisis pengaruh dari campuran lilin parafin dan serbuk daun pepaya terhadap keberadaan lalat di Pasar Manis Purwokerto Banyumas

Berdasarkan hasil penelitian untuk menganalisis pengaruh dari campuran lilin parafin dan serbuk daun pepaya terhadap keberadaan lalat peneliti menggunakan uji tabel dimana dilakukan perbandingan hasil antara sebelum perlakuan dan sesudah perlakuan. Adapun rinciannya dapat dilihat pada tabel 1 yaitu pada 
perlakuan kontrol terdapat 1 lalat yang hinggap di sampling frame zona $B$ pada pagi di hari ke dua dan siang di hari ke dua, pada perlakuan 10 gram terdapat 1 lalat yang hinggap di sampling frame zona B pada pagi di hari ke dua dan sore di hari pertama, pada perlakuan 20 gram terdapat 1 lalat yang hinggap di sampling frame zona B pada pagi di hari pertama dan siang di hari ke tiga, sedangkan pada perlakuan 30 gram terdapat 1 lalat yang hinggap di sampling frame zona B pada siang di hari ke tiga. Berdasarkan hasil tersebut yang paling berpengaruh dalam mengusir lalat yaitu dosis 30 gram serta waktu yang paling banyak terdapat lalat yaitu pada waktu pagi dan siang

Hasil diatas tidak terlepas dari pengaruh kondisi lingkungan dimana kelembaban udara sangat berpengaruh bagi kepadatan lalat, hal ini dijelaskan bahwa jika suhu udara dibawah atau dingin maka kelembaban udara tinggi yang juga diikuti oleh perubahan tingkat kepadatan lalat yang menunjukkan tingkat kepadatan lalat meningkat. Selain itu kecepatan angin berpengaruh bagi kepadatan lalat, hal ini dijelaskan bahwa jika kecepatan angin rendah maka lalat akan meningkat dan apabila kecepatan angin kencang (tinggi) maka lalat yang hinggap sedikit atau menurun (Desta Puji Rusiana, 2018, h.32) .

Menurut Ditjen PPM dan PL (2001, h. 6) lalat merupakan serangga yang bersifat fototropik yaitu menyukai cahaya. Pada malam hari tidak efektif, namun dapat aktif dengan adanya sinar buatan. Efek sinar pada lalat tergantung sepenuhnya pada temperatur dan kelembaban. Dapat ditarik kesimpulan, jika keduanya (temperatur dan kelembaban) dapat menjadikan lalat berkembangbiak secara optimum, pencahayaannya pun dapat dijadikan kondisi yang mempengaruhi adanya suatu kepadatan lalat di tempat tersebut

Selain itu berdasarkan hasil diatas waktu yang paling banyak dihinggapi oleh lalat yaitu pada waktu pagi dan siang, hal ini sesuai dengan bionomic lalat menurut Ditjen PPM \& PLP (1991) lalat beristirahat pada tempat tertentu. Pada siang hari bila lalat tidak makan mereka akan beristirahat pada lantai, dinding, langit - langit, jemuran pakaian, rumput - rumput, kawat litrik dan lain - lain serta sangat menyukai tempat tempat dengan tepi tajam yang permukaannya vertical.

IV. Kesimpulan dan Saran

A. Kesimpulan

1. Terdapat lalat di zona B pada radius nyala lilin dengan jari - jari $8 \mathrm{~cm}$

2. Total terdapat 7 lalat yang berada di area nyala lilin

3. Jika temperatur dan kelembaban dapat menjadikan lalat berkembangbiak secara optimum, maka pencahayaannya dan kecepatan angina pun dapat dijadikan kondisi yang mempengaruhi adanya suatu kepadatan lalat di tempat tersebut

4. Jenis lalat yang terdapat diarea nyala lilin yaitu jenis lalat Musca Domestica dengan jumlah 5 ekor dan jenis lalat Lucilia Sericata dengan jumlah 2 ekor

5. Dosis yang paling efektif dalam mengusir keberadaan lalat yaitu dosis 30 gram.

6. Ada pengaruh pemakaian campuran lilin parafin dan serbuk daun pepaya terhadap keberadaan lalat

B. Saran

1. Bagi pihak pengelola pasar manis diharapkan melakukan perbaikan hygiene dan sarana sanitasi lingkungan dengan cara mengeliminasi tempat-tempat perindukan lalat dengan melakukan menambah pengangkutan sampah dari TPS ke TPA yang semula dilakukan setiap 3 hari sekali menjadi 1 kali sehari

2. Perlu dilakukan penelitian lanjutan mengenai pengaruh dari daun pepaya sebagai insektisida nabati

3. Bagi kalangan pendidik hasil penelitian ini bisa digunakan sebagai alternatif sumber belajar biologi, referensi, dan penambah pengetahuan

V. Daftar Pustaka

Agus Subagyo, dkk 2013. Densitas dan Identifikasi Lalat Serta Upaya Pengendaliannya di Pasar Tradisional Purwokerto. Purwokerto: Jurusan Teknik Radiodiagnostik dan Radioterapi Purwokerto, Poltekkes Kemenkes Semarang.

https://media.neliti.com/media/publications/1 32867-ID-none.pdf Diakses pada 20 Februari 2019 pukul 14.00 
Dicky Andiarsa, Ika Setianingsih, Abdullah Fadilly, Syarif Hidayat, Dian Eka Setyaningtyas, Budi Hairani. 2015. Gambaran Bakteriologis Lalat Dan Culicidae (Ordo:Diptera) di Lingkungan Balai Litbang P2B2 Tanah Bambu. Kalimantan Selatan: Balai Litbang P2B2 Tanah Bumbu, Badan Litbang Kesehatan, Kementerian Kesehatan RI

http://ejournal.litbang.depkes.go.id/index.php /vektorp/article/download/5716/5032. Diakses pada 14 Desember 2018 pukul 06.24

Desta Puji Rusiani. 2018. Studi Variasi Warna Fly Grill Terhadap Hasil Perhitungan Kepadatan Lalat Di Tps Pasar Manis Purwokerto Kabupaten Banyumas Tahun 2018. KTI. Purwokerto. Poltekkes Kemenkes Semarang Jurusan D3 Kesehatan Lingkungan.http://repository.poltekkess mg.ac.id/index.php?p=show_detail\&id= $17328 \&$ keywords $=$ Diakses pada 5 Mei 2019 pukul 10.58

Ditjen PPM dan PLP. 1991. Petunjuk Teknis Tentang Pemberantasan Lalat, Jakarta: Depkes R.I.

Endang Puji Astuti dan Firda Yanuar pradani. 2010. Pertumbuhan dan Reproduksi Lalat Musca domestica pada Berbagai Media Perkembangbiakan. Ciamis : loka Litbang P2B2 Ciamis.

https://ejournal2.litbang.kemkes.go.id/index.p hp/aspirator/article/view/1765. Diakses pada 7 Mei 2019 pada pukul 08.50

Konno, K dkk. 2004. Papain Protecs Pepaya Trees from Herbivorous Insects: Role of Cysteine Proteases in Latex. Blackwell Publishing Ltd. The Plant Journal 37: 370-378

Nani Kurnia, Rahmat Baharuddin, Rosdiana Ngitung, Army Auliah. 2018. Lalat Hijau Lucilia sericata sebagai Agen Biokonversi Sampah Organik: Pengamatan Siklus Hidup. Makassar : Jurusan Biologi, FMIPA, Universitas Negeri Makassar.

http://ojs.unm.ac.id/semnasbio/article/downlo ad/7969/4624. Diakses pada 13 Mei 2019 Pukul 13.25
Profil Kesehatan Kabupaten Banyumas Tahun 2015, Banyumas: Dinkes Kabupaten Banyumas

Puguh Wahyudi, Susi Soviana, Upik Kesumawati Hadi. 2015. Keragaman Jenis dan Prevalensi Lalat Pasar Tradisional di Kota Bogor. Bogor : Direktorat Jenderal Peternakan dan Kesehatan Hewan, Kementrian Pertanian Republik IndonesiaBagian Parasitologi dan Entomologi Kesehatan, Fakultas Kedokteran Hewan, Institut Pertanian Bogor.

http://ejournal.unud.ac.id/php.index/jvet. Diakses pada 7 Mei 2019 Pukul 15.22

Sapta Raharja, Dwi Setyaningsih dan Doris Monica Sari Turnip. 2006. Pengaruh Perbedaan Komposisi Bahan, Konsentrasi Dan Jenis Minyak Atsiri Pada Pembuatan Lilin Aromaterapi. Bogor : Jurusan Teknologi Industri Pertanian, Fakultas Teknologi Pertanian, Kampus IPB Darmaga.

http://ejournals.unmul.ac.id/index.php/TAF/a rticle/download/1767/133. Diakses pada 6 Mei 2019 pukul 12.54

Triana Wulandari. 2017. Pemanfaatan Ekstrak Daun Pepaya (Carica Papaya L.) Untuk Pengendalian Hama Kutu Daun (Aphis Sp.) Pada Tanaman Cabai (Capsicum Annuum L.) . Skripsi. Yogyakarta : Program Studi Agroteknologi, Fakultas Pertanian Universitas MuhammadiyahYogyakarta.

http://repository.umy.ac.id/bitstream/handle/1 23456789/15216/k.\%20Naskah\%20Publi kasi.pdf?sequence $=11 \&$ is Allowed $=y$. Diakses pada 12 Mei 2019 pukul 16.27

Undang-undang Republik Indonesia Nomor 36 Tahun 2009 tentang Kesehatan, Jakarta: Presiden Republik Indonesia.

Yuli Patmasari, Lucky Herawati, Sarjito Eko Windarso. 2014. Pengaruh Konsentrasi Minyak Serai Wangi (Citronela Oil) Dalam Lilin Padat Terhadap Penurunan Kepadatan Lalat Rumah (Musca Domestica) Di Warung Makan Sepanjang Pantai Depok. Yogyakarta: JKL Poltekkes Kemenkes Yogyakarta. http://eprints.poltekkesjogja.ac.id/24/. Diakses pada 14 Desember 2018 pukul 11.19 